\title{
Kuluttajanäkökulmia eläinten hyvinvointimerkin kehittämiseen
}

\author{
Heinola Katriina $^{1)}$, Latvala Terhi ${ }^{1)}$, Raussi Satu ${ }^{2)}$, Kauppinen Tiina ${ }^{2)}$ ja Niemi Jarkko K. ${ }^{1)}$ \\ 1)Luonnonvarakeskus, Latokartanonkaari 9,00790 Helsinki, katriina.heinola@luke.fi, \\ terhi.latvala@luke.fi jarkko.niemi@luke.fi \\ 2) Eläinten hyvinvointikeskus, Luonnonvarakeskus, Latokartanonkaari 9, 00790 Helsinki, \\ tiina.kauppinen@luke.fi,satu.raussi@luke.fi
}

\section{TIIVISTELMÄ}

Selvitimme suomalaisten odotuksia tuotantoeläinten hyvinvoinnista ja sitä, millainen merkitys eläinten hyvinvointia edistävillä toimenpiteillä ja eläinten hyvinvoinnista kertovilla pakkausmerkinnöillä eläinperäisissä elintarvikkeissa on kuluttajille. Kuluttajatutkimuksen pääasiallisena tarkoituksena oli lisätä ymmärtämystä siitä, mitkä ovat kuluttajien huolenaiheita ja toisaalta kiinnostuksen kohteita eläinten hyvinvointimerkinnässä, ja miten merkintä voitaisiin parhaiten lanseerata kuluttajien keskuudessa. Keskeinen kysymys on, tulisiko suomalaisille eläintuotteille kehittää merkintä, joka edistäisi eläinten hyvinvointia ja toisi näkyvästi esiin eläinten hyvinvoinnin eteen tehtäviä toimenpiteitä tiloilla.

Tieteellinen ymmärrys tuotantoeläinten hyvinvoinnin osatekijöistä paranee jatkuvasti. Sitä kautta ymmärrys kasvaa myös kuluttajien keskuudessa. Eläinten hyvinvoinnin tieteelliseen mittaamiseen on kehitetty Welfare Quality ${ }^{\circledR}$ mittaristo (WQ). Kuluttajien mielipiteissä WQ:n eri osa-alueiden tärkeydestä korostuivat laajasti hyvinvoinnin eri osa-alueet: eläimen perustarpeet, kuten janon ja nälän tyydyttyminen sekä hyvä terveys, olosuhteiden, tilan, liikkumismahdollisuuksien ja hyvän hoidon merkitys sekä eläinten mahdollisuudet lajinmukaiseen käyttäytymiseen ja vuorovaikutukseen ihmisten ja toisten eläinten kanssa.

Vuoden 2018 aikana toteutettiin kolme laajaa kuluttajakyselyä. Kuluttajakyselyn perusteella kuluttajille tärkeimpiä hyvinvoinnin osa-alueita olivat vastaajien mielestä eläimen terveyteen ja ravitsemukseen liittyvät tekijät, mutta yli 80 \% vastaajista piti muitakin osa-alueita tärkeinä. Kuluttajien näkökulmasta tärkeimpiä ovat eläinten perustarpeisiin liittyvät kysymykset, kuten jano, nälkä, terveys. Toiseksi tärkein ominaisuusryhmä liittyy eläimen olosuhteisiin, jolloin tuotantoeläimille mahdollisestaan vapaana liikkuminen, riittävästi tilaa, pehmeä makuualusta ja hyvä hoito. Kolmanneksi tärkein osa-alue liittyy vuorovaikutukseen ja käyttäytymiseen, jolloin mahdollisestaan lajinomainen käyttäytyminen, hyvä hoitaja-eläin-suhde, eläintenvälinen sosiaalisuus sekä erilaiset tunnetilat, kuten leikkisyys.

Vastaajista $65 \%$ arvioi, että ostaisi hyvinvointimerkittyjä tuotteita, jos kotieläintuotannossa keskityttäisiin enemmän eläinten hyvinvointiin. Puolet vastaajista oli ostanut tuotantotapamerkittyjä eläintuotteita esimerkiksi luomumerkin avulla. Jos Suomen markkinoille tuotaisiin uusi hyvinvointimerkki, kolme neljäsosaa vastaajista koki mahdollisen hyvinvointimerkityn tuotteen ostamisen myönteisesti ja $14 \%$ vastaajista koki merkinnän tarpeettomaksi. Kaksi kolmasosaa uskoi merkinnällä varustetun tuotteen ostamisen parantavan eläinten hyvinvointia myös käytännössä.

Asiasanat: eläinten hyvinvointi, kuluttajat, eläinten hyvinvointimerkki

\section{Johdanto}

Yhtäältä kiinnostus ja toisaalta huolestuneisuus eläinten hyvinvointia kohtaan ovat olleet esillä viime vuosina. Julkinen keskustelu on liittynyt erityisesti erilaisiin tuotantotapoihin sekä eläinten hyvinvoinnin tasoon, valvontaan ja lainsäädännön rikkomuksiin (MMM 2020). Huoli eläinten hyvinvoinnista on johtanut siihen, että etenkin Euroopassa ja Pohjois-Amerikassa on kehitetty eläinten hyvinvointimerkintäjärjestelmiä, jotka näkyvät kuluttajalle saakka pakkausmerkintänä. Eläinten hyvinvointimerkintäjärjestelmän tavoitteena on samanaikainen tuotantoeläinten hyvinvoinnin edistäminen sekä tuotannon läpinäkyvyyden parantaminen eläintuotannon käytännöistä kuluttajalle. 
Suomessa ei vielä ole yhdenmukaista useaa tuotantoeläinlajia kattavaa hyvinvointijärjestelmää. Kansainvälinen tieteellisesti tutkittuun tietoon perustuva eläinten hyvinvoinnin mittausmenetelmä, Welfare Quality ${ }^{\circledR}$ (Botreau ym. 2007, Botreau ym. 2009), on käytössä osassa kotimaista maidontuotantoa, Juustonportin Vapaan lehmän maidossa sekä Lidlin myymässä Ilona-maidossa (Juustoportti 2020, Lidl 2020). Myös maatalouspoliittisella ohjauksella tuetaan eläinten hyvinvointia parantavia toimenpiteitä ja eläinten hyvinvointituki kannustaa tuottajia erilaisiin hyvinvointitoimenpiteisiin. Tukea maksetaan vain eläinsuojelulainsäädännön (Eläinsuojelulaki 247/1996, Eläinsuojeluasetus 396/1996) ylittäville toimenpiteille. Myös luomutuotannossa eläinten hyvinvointiin, etenkin lajinmukaiseen käyttäytymiseen, panostetaan tavanomaista tuotantoa enemmän (Laki eräistä ohjelmaperusteisista viljelijäasetuksista 1360/2014). Sianlihantuotannossa on käytössä kansallinen sikojen terveydenhuoltojärjestelmään perustuva laatujärjestelmä, joka näkyy kuluttajille terminä 'Laatuvastuu' (Ruokavirasto 2020).

Suomessa eläintautitilanne on maailmanlaajuisestikin verrattuna hyvä (Ruokavirasto 2019). Suomessa on kattavat eläinten terveydenhuoltojärjestelmät, jotka ovat laajasti käytössä etenkin naudoilla ja sioilla. Eläinsuojelulaki ja asetus kieltävät useat mutilaatiot eli esimerkiksi hännän typistyksen tai nokan katkaisun, joita käytetään yleisesti muiden maiden eläintuotannossa. Vapaaehtoisesti eli yli lainsäädännön vaatimusten esimerkiksi nautojen hyvinvointia edistetään $\mathrm{mm}$. varmistamalla makuupaikan mukavuus puhtaalla, kuivalla ja pehmeällä alustalla ja riittävällä tilalla, vapaasti saatavilla olevalla vedellä sekä eläinlääkärin suorittamalla nupoutuksella kivunlievitystä ja paikallispuudutusta käyttäen. Muissakin tuotantomuodoissa eläinten hyvinvointia edistävät lajinmukainen ruokinta, vapaus liikkua, makuualustan puhtaus, kuivuus ja mukavuus, lisätila sekä eläimille tarjotut, lajinmukaista käyttäytymistä edistävät virikkeet (EHK 2016). Eläinsuojelulain uudistaminen on kehitteillä Suomessa (MMM 2018) ja se on tuonut keskustelua muun muassa lehmien pidosta parsinavetoissa ja pihatoissa ja sikojen tiineytys- ja porsitushäkkien käytöstä. Sikojen vapaaporsitus on lisääntynyt, mutta edelleen häkkiporsitus on vallitseva tapa. Kananmunantuotannon osalta suuret kauppaketjut kuten S-ryhmä, Kryhmä ja Lidl ovat ilmoittaneet luopuvansa virikehäkeissä tuotetuista munista siirtyen vapaan kanan muniin, joten muutoksia myös vähittäiskaupan taholta on tapahtumassa.

Hyvinvointimerkintäjärjestelmät tuovat kustannuksia toimijoille esimerkiksi hyvinvointivaatimuksiin liittyvien investointien, hankintojen tai kasvaneen työajan muodossa sekä järjestelmän todentamisen, valvonnan, raaka-aineiden erillään pitämisen, jäljitettävyyden ja markkinoinnin muodossa. Nämä kustannukset on katettava tuotteista saatavalla lisähinnalla. Tarkastelimme kuluttajalle suunnattujen kolmen laajan kyselyn avulla kuluttajien mielipiteitä suomalaisen eläintuotannon tasosta ja eläinten hyvinvointia edistävien toimenpiteiden tärkeydestä eläinlajeittain. Kuluttajien mieltymysten ja näkemysten tunnistaminen on tärkeää, jotta merkkiä voidaan kehittää markkinaehtoisesti.

\section{Materiaali ja menetelmät}

\section{Hyvinvointitoimenpiteiden valinta}

\section{Toimenpiteiden määrittely asiantuntijatyönä}

Eri tuotantoeläimille ehdotetut hyvinvointitoimenpiteet perustuivat tieteelliseen kirjallisuuteen eläinten hyvinvoinnista sekä sidosryhmäasiantuntijoiden kanssa pidettyihin työpajoihin sekä sidosryhmille tehtyyn kyselyyn hyvinvointikriteerien tärkeydestä. Tutkimus on osa projektia, jonka yksi työpaketti keskittyi hyvinvointia edistävien tekijöiden kartoittamiseen (Wallenius 2020). Lisäksi järjestettiin kymmenen työpajaa erikseen siipikarja-alan asiantuntijoille, eläinsuojelujärjestöille, eläinten hyvinvoinnin ja kuluttajatutkimuksen tutkijoille, meijerialalle, päivittäistavarakaupalle, lihateollisuudelle, ETT Eläinten terveys -yhdistykselle sekä edunvalvonnalle/ tuottajaorganisaatioille. Työpajoissa keskusteltiin hyvinvointimerkintäjärjestelmän perustamisesta yleisellä tasolla. Sidosryhmille tehdyssä kyselyssä tarkasteltiin vielä tarkemmin asiantuntijoiden näkemystä hyvinvointitoimenpiteiden tärkeydestä suhteessa toisiinsa.

Tarkasteltaessa vastaajien mielipidettä eläinten hyvinvoinnin eri osa-alueista hyödynnettiin myös kansainvälistä Welfare Quality® (WQ) -mittausmenetelmää (Welfare Quality 2018). WQ huomioi neljä 
eri osa-aluetta: hyvä ruokinta, hyvä kasvatusympäristö, hyvä terveys ja käyttäytyminen. Menetelmä sisältää myös eläinperäisiä mittareita, kuten eläimen ihon kunto tai käyttäytyminen, resurssiperäisten mittareiden lisäksi. Resurssiperäiset mittarit, kuten pehkun määrä, ovat eläinperäisiä mittareita helpompia ja usein myös edullisempia valvoa. Resurssiperäiset mittarit ovat hyvinvointivointijärjestelmissä enemmän käytettyjä kuin eläinperäiset mittarit, edellä mainituista syistä.

\section{Eri tuotantoeläimille ehdotetut toimenpiteet}

Tuotantoeläimille valikoidut hyvinvointitoimenpiteet edistävät lajinmukaista käyttäytymistä (virikkeet, lajinmukainen ruokinta, liikkumisen vapaus), hyvää kasvatusympäristöä (mukava makuualusta ja pehku, usein ulkoilumahdollisuus), hyvää ruokintaa ja vedensaantia sekä ennaltaehkäisevää terveydenhuoltoa. Myös eläinten mahdollisuudet saada hyvää kohtelua sekä tuntea positiivisia tunnetiloja hoitajan asiantuntemuksen kautta huomioitiin kriteerillä, jossa hoitaja käy eläinten hyvään kohteluun ja käsittelyyn liittyvän koulutuksen. Eläimen positiiviset tunteet, niiden (toiminnallinen) yhdistäminen tavoitekäyttäytymiseen, elämänlaatu sekä onnellisuus liitetään positiiviseen eläinten hyvinvointiin, joka painottaa eläimen mahdollisuutta elää hyvää elämää (Lawrence ym. 2019). Hyvän kohtelun ja positiivisten tunnetilojen arviointia voidaan tehdä esimerkiksi leikkikäyttäytymisen tai tietynlaisen tunnetilaa ilmentävän ääntelyn perusteella (Boissy ym. 2007). Sikojen hyvinvointikriteereiksi esitettiin hyvää kohtelu ja käsittely -koulutusta hoitajille, ennaltaehkäisevää terveydenhuoltoa, lisäelintilaa, hyvinvointi-indeksiä (hyvinvoinnin säännöllinen mittaaminen useista tekijöistä), laadukkaan tonkimismateriaalin tarjoamista niin, että materiaalia on aina saatavilla, vapaata porsimista, ulkoilumahdollisuutta sekä tiineytystä ilman häkissä pitoa. Esimerkiksi lisätilalla on havaittu positiivisia vaikutuksia ihon kuntoon sekä kasvunopeuteen (Barnett ym. 2000, Turner ym. 2000). Monet tekijät vaikuttavat myös sian käyttäytymiseen, kuten vähäinen tila ja riittämätön ruokinta sekä virikkeiden vähäinen tarjonta (Scollo ym.2016, Vermeer ym 2017) Vapaa porsitus edistää emakon liikkumisen vapautta, luontaista käyttäytymistä sekä kontaktia porsaisiin sekä mahdollistaa pesänrakennuskäyttäytymisen (Wischner ym. 2009, EHK 2013a).

Nautojen hyvinvointitekijöinä tarkasteltiin ulkoilu- ja jaloittelumahdollisuutta talvikaudella, pehmeää makuualustaa, karkearehun jatkuva saantia, jalkaterveyden seurantaa, ennaltaehkäisevää terveydenhuoltoa, hyvä kohtelu ja käsittely -koulutusta sekä jatkuvaa vedensaantia. Lisäksi lihanautojen osalta tarkasteltiin lisäelintilaa ja lehmien osalta laidunnusta kesäkaudella sekä vapaata liikkumista (pihattonavetta) ja vasikoiden osalta imemistarpeen tyydyttämistä sekä runsaampaa juottoa. Esimerkiksi laidunnuksella on monia positiivia vaikutuksia mm. ontumisen vähenemiseen, utaretulehduksiin sekä lajinmukaiseen käyttäytymiseen (Washburn ym. 2002, Hernandez-Mendo ym 2007, Roca-Fernandez 2013), jota edistää ylipäätään mahdollisuus vapaaseen liikkumiseen kytkemiseen verrattuna (von Keyserlingk ym. 2000). Lampaiden hyvinvointia edistäviksi toimenpiteiksi valikoituivat jatkuva vedensaanti, laidunnusmahdollisuus, ulkoilu- ja jaloittelumahdollisuus laidunkauden ulkopuolella, karitsoinnin valvonta, keritseminen kahdesti vuodessa, ennaltaehkäisevä terveydenhuolto sekä hyvä kohtelu ja käsittely -koulutus. Esimerkiksi karitsoinnin valvonnalla ja siihen liittyvillä tekijöillä kuten maidonsaannilla on merkittävä vaikutus karitsakuolleisuuteen (Dvyer 2008).

Broilereilla ja munivilla kanoilla hyvinvointitoimenpiteinä tarkasteltiin lisäelintilaa, ennaltaehkäisevää terveydenhuoltoa, hyvä kohtelu ja käsittely -koulutusta, virikkeiden tai lajinomaisen käytöksen mahdollistavien tekijöiden käyttöä, kuten broilereilla ritilätasoja ja kanoilla kuopsutus- ja kylpemismahdollisuutta. Kanoilla hyvinvointitekijöitä olivat edellä mainittujen lisäksi ulkoilumahdollisuus, ilmanlaadun seuranta, vapaa liikkuminen sekä lajinomainen ruokinta (esim. kokonaiset jyvät). Broilereille hyvinvointitekijöitä olivat lisäksi hitaammin kasvava rotu, jalkaterveyden ennaltaehkäisevä seuranta tilalla sekä mukava alusta. Broilerien osalta esimerkiksi hyvällä makuualustamateriaalilla on monia hyvinvointivaikutuksia, kuten jalkaterveyden ja yleensä terveyden edistyminen (Dawkins ym. 2004, Bessey 2006). 


\section{Kuluttajakysely}

Syksyllä 2018 toteutettiin kolme laajaa kuluttajakyselyä, joista kukin keskittyi tiettyyn eläinlajiin tai eläinlajeihin. Nautoihin liittyviä kysely tarkasteli maidontuotantoon ja naudanlihantuotantoon, siipikarjaan liittyvä kysely kananmunantuotantoon ja broilerintuotantoon ja kolmas sianlihantuotantoon ja lampaanlihantuotantoon liittyviä tekijöitä yhteisten yleisempien kysymyksien lisäksi. Kyselyt toteutettiin ostopalveluna ja kuhunkin kyselyyn saatiin vastaukset 400 vastaajalta. Kyselyssä huomioitiin myös kuluttajan näkemykset järjestelmän rahoituksesta ja valvonnasta, yleisistä kulutustottumuksista ja niiden muutoksista sekä kuluttajan tietoisuudesta ja yhteyksistä nykyiseen eläintuotantoon.

\section{Vastaajat ja heidän tietoisuus eläintuotannosta}

Vastaajien $(n=1200)$ taustatietoja on esitetty taulukossa 1 . Naisia vastaajista oli 51 prosenttia, mikä vastaa koko myös koko maan osuutta. Yli 65 vuotiaita oli vastaajista 24 \% ja $18-24$ vuotiaita $11 \%$. Taulukossa on esitetty myös koko maan edustavuus prosentteina (18 vuodesta ylöspäin, SVT 2020a). Yli 65-vuotiaat ovat tutkimuksessa hieman aliedustettuina, mikä voi johtua tutkimuksen sähköisestä tiedonkeruutavasta. Vastaajista $18 \%$ ei kertonut tulojaan, joten niitä on haastava verrata koko maan kotitalouksien tuloihin. Koko maassa kotitalouksista alle 20 tuhatta euroa tienasi 21\%, 20-40 tuhatta euroa $29 \%, 40-70$ tuhatta $27 \%, 70-100$ tuhatta euroa $14 \%, 100-120$ tuhatta euroa $4 \%$ ja yli 120 tuhatta euroa $5 \%$ (SVT 2020b). Koulutuksen osalta koko maassa 20 vuotta täyttäneistä korkea-asteen tutkinnon on suorittanut $34 \%$ (SVT 2020c) ja tutkimuksessa $38 \%$, eli hieman korkeampi osuus. Toisen asteen suorittaneita koko maassa oli (vuonna 2018) $42 \%$ ja ilman peruskoulun jälkeistä tutkintoa $23 \%$, yli 20 vuotta täyttäneistä koko maassa. Vertailuun tuo kuitenkin haasteita se, että tutkimukseen vastasivat vain yli 18-vuotiaat, mutta koko maan tiedoissa ikäjakaumatiedot esittävät yli 20-vuotiasta väestöä. Vastaajista kokopäivätyössä oli $37 \%$, osa-aikatyössä $7 \%$, yrittäjiä $2 \%$, eläkkeellä $33 \%$ ja opiskelijoita $9 \%$. Työttömiä oli $8 \%$ ja muussa elämänvaiheessa $3 \%$. Koko maassa yli 18-vuotiaista vuonna 2018 työllisiä oli $53 \%$ ja työttömiä oli $6 \%$, eläkeläisiä $32 \%$ ja opiskelijoita $5 \%$. Muita ryhmiä, kuten varusmiehiä ja muuten työvoiman ulkopuolella olevia oli 5 \% (SVT 2020d) väestöstä.

Taulukko 1. Vastaajien sukupuolijakauma, ikä (myös koko maassa) ja koulutus, \% vastaajista (n=1200)

\begin{tabular}{ll|ll|ll}
\hline Sukupuoli ja ikä & $\%$ (maassa) & Kotitalouden tulot, tuhat $€$ & $\%$ & Koulutus & $\%$ \\
\hline Nainen & $51(51)$ & $>20 €$ & 18 & Ei peruskoulutusta & 1 \\
$18-24 \mathrm{v}$. & $11(10)$ & $20-40$ & 26 & Ylempi perusaste & 8 \\
$25-34 \mathrm{v}$. & $16(16)$ & $40-60$ & 17 & Opistoaste & 14 \\
$35-44 \mathrm{v}$. & $15(15)$ & $60-80$ & 11 & Toisen asteen koulutus & 37 \\
$45-54 \mathrm{v}$. & $17(15)$ & $80-120$ & 8 & Alempi & 23 \\
& & & korkeakouluaste & 13 \\
$55-64 \mathrm{v}$. & $17(16)$ & yli 121 & 2 & Ylempi & korkeakouluaste \\
& & & 18 & Tutkijakoulutusaste & 2 \\
$65+\mathrm{v}$ & $24(28)$ & Ei tiedossa & & Muu & 2 \\
\hline
\end{tabular}

Vastaajista kolmannes on vieraillut tuotantotilalla viiden viimeisen vuoden aikana. Kysyttäessä yhteyksistä eläintuotantoon, $45 \%$ vastaajilla ei ollut työskennellyt ja $3 \%$ työskenteli tai oli työskennellyt tilalla, $26 \%$ :n lähisukulaisella oli tila ja 13\% oli asunut maatilalla tai asui kyselyhetkellä. Vastaajilta kysyttiin myös heidän omaa subjektiivista näkemystään siitä, kuinka paljon he kokevat tietävänsä nykyisestä eläintuotannosta. Runsas kolmannes eli $35 \%$ koki tietävänsä vähän ja $6 \%$ ei lainkaan. Paljon koki tietävänsä $3 \%$ ja melko paljon $13 \%$. Jonkin verran arveli tietävänsä $43 \%$. 


\section{Tulokset}

\section{Eläinten hyvinvoinnin eri osa-alueiden tärkeys ja tuotantoeläinten hyvinvoinnin kehitys}

Eläinten hyvinvoinnin osa-alueet perustuvat WQ mittausmenetelmän osa-alueisiin (Canali ja Keeling 2016, Welfare Quality 2018). Hyvään ruokintaan liittyvinä osa-alueina kysyttiin lajinmukaisen ja terveyttä edistävän ravinnon sekä "Ei pitkittynyttä janoa tai nälkää”-tekijän tärkeyttä. Hyvään terveyteen liittyvät tekijät olivat "Ei koe hoitotoimenpiteitä kipua, ei merkittävissä määrin sairauksia, ei merkittävissä määrin vammoja”. Hyvään kasvatusympäristöön liittyvät liikkumisen helppous, mukava lämpötila kasvatusympäristössä sekä makuualustan mukavuus. Eläinperäisiä resursseja tuovat esiin lajinmukaisen käyttäytymisen mahdollistavat tekijät, kuten mahdollisuus kokea positiivia tunnetiloja, hyvä eläimen ja hoitajan välinen suhde, mahdollisuus hoitaa jälkeläisiä, mahdollisuus sosiaaliseen käyttäytymiseen muiden eläinten kanssa, ja mahdollisuus lajinomaiseen syömiskäyttäytymiseen.

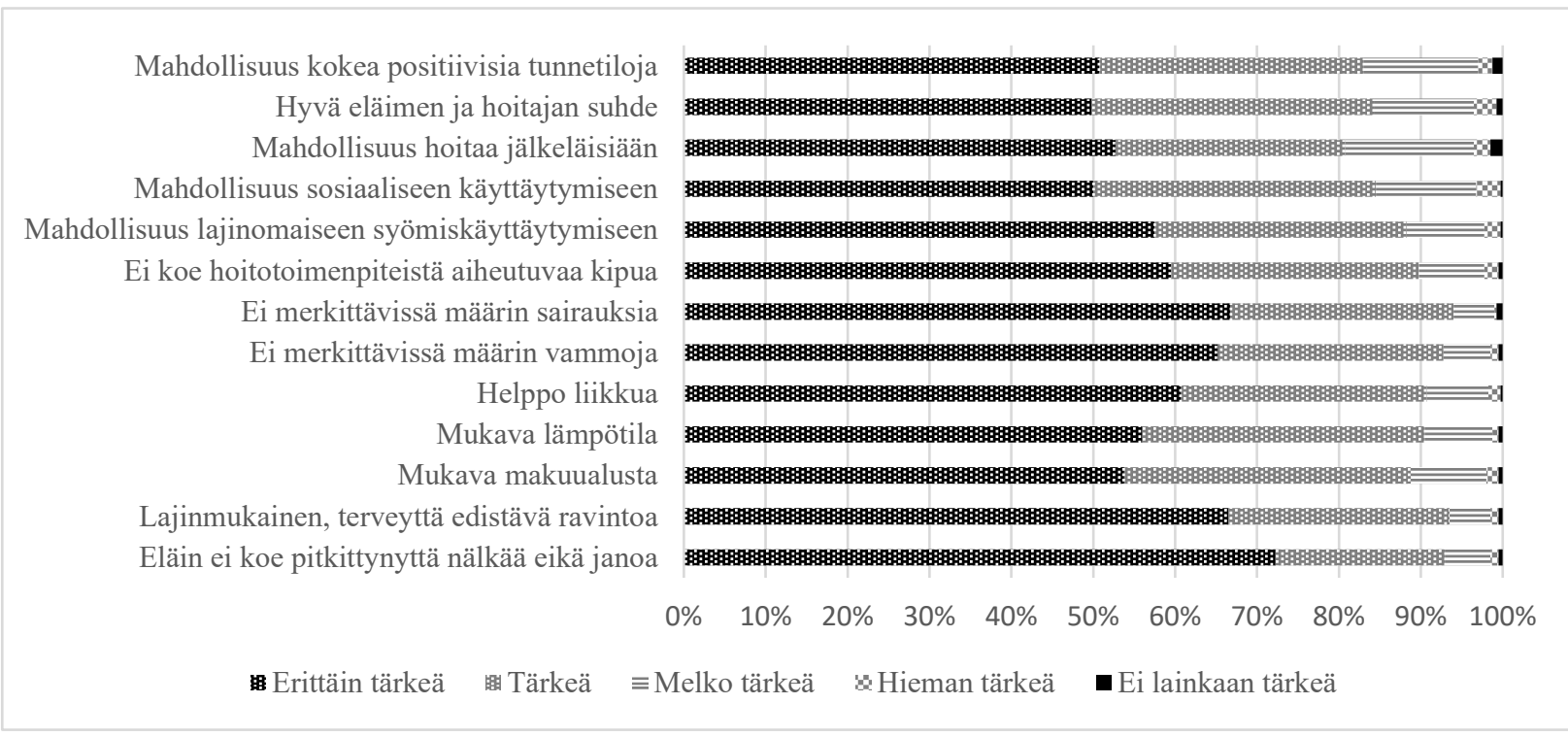

Kuva 1. Vastaajien mielipide eläinten hyvinvoinnin eri osa-alueiden tärkeydestä $(n=400)$

Vastaajien mielipidettä kysyttiin viisiportaisella asteikolla vastausvaihtoehtojen ollessa ei lainkaan tärkeästä erittäin tärkeään. Tärkeimmäksi osa-alueeksi nähtiin ravintoon liittyvä tekijät, joita pidettiin erittäin tärkeinä tai tärkeinä yli $90 \%$ mielestä (Kuva 1). Myös terveyteen liittyvät tekijät koettiin tärkeiksi. Mahdollisuus hoitaa jälkeläisiä, sekä eläimen ja hoitajan välinen suhde ja mahdollisuus positiivisiin tunnetiloihin nähtiin muihin verrattuina harvemmin tärkeiksi, mutta silti tekijöitä piti vähintään tärkeinä yli $80 \%$ vastaajista. Kyselyissä tarkasteltiin vastaajien näkemystä eläinten hyvinvoinnin kehittymisestä $(\mathrm{n}=1200)$. Vastaajista $44 \%$ oli sitä mieltä, että tuotantoeläinten hyvinvointi on parantunut viimeisen 10 vuoden aikana. Vain $11 \%$ :n mielestä hyvinvointi on heikentynyt, kun taas $31 \%$ oli sitä mieltä, että hyvinvointi on pysynyt ennallaan. Kyselyssä kysyttiin myös vastaajien näkemystä hyvinvoinnin tulevan 10 vuoden kehityksestä. Vastaukset olivat hyvin samankaltaisia viime vuosien kehityksen kanssa; 49 \% uskoi hyvinvoinnin parantuvan, 31 \% oli sitä mieltä, että hyvinvointi pysyy samana ja $10 \%$ vastaajista näki hyvinvoinnin heikkenevän. Paranemisen syyksi esitettiin muun muassa kuluttajien lisääntynyttä tietoisuutta ja vaatimustasoa, viranomaisten valvonnan tehostumista ja uusia tuotantoteknologioita ja heikkenemisen syiksi tilakoon ja tehokkuuden kasvia, vähäistä puuttumista epäkohtiin sekä tuottajien taloustilanteen ja jaksamisen heikentymistä.

\section{Kuluttajien mielikuva hyvinvoinnista eri tuotantomuodoissa}

Vastaajien $(\mathrm{n}=400)$ mielikuva tuotantoeläinten hyvinvoinnista on esitetty lajeittain sekä tuotantomuodoin- ja vaihein Taulukossa 2. Prosenttiosuus kuvaa niiden vastaajien osuutta, jotka näkivät kussakin tuotantomuodossa hyvinvoinnin hyvänä tai erittäin hyvänä. Vastaajille esitettiin neutraali 
kuvaus kustakin esitetystä vaiheesta. Kaiken kaikkiaan "vapaissa" (ei kiinnipitoa kytkettyä) tuotantomuodoissa hyvinvoinnin nähtiin olevan korkeimmalla tasolla, kuten sikojen osalta häkittömässä (vapaassa) porsituksessa tai tiineytyksessä, lehmillä, lihanaudoilla tai lampailla pihatossa ja kanoilla ulko- tai lattiakanaloissa. Teurastukseen liittyvät tuotantovaiheet ja broilerien hyvinvointi sekä etenkin lihanautojen kasvatus ryhmäkarsinassa nähtiin heikoimmaksi.

Taulukko 2. Osuus vastaajista, joiden mielestä hyvinvointi on tuotantomuodossa hyvä tai erittäin hyvä

\begin{tabular}{|l|c|l|c|}
\hline Lihanaudat & $\mathbf{\%}$ & Siat & $\mathbf{\%}$ \\
\hline Lihanauta emolehmätuotannossa & $\mathbf{7 4}$ & Vapaa porsitus & $\mathbf{7 4}$ \\
\hline Lihanauta pihatossa & $\mathbf{6 3}$ & Ei käytetä tiineytyshäkkiä & $\mathbf{6 5}$ \\
\hline Naudat ennen teurastusta & $\mathbf{4 1}$ & Sikojen teuraskuljetus & $\mathbf{4 9}$ \\
\hline Nautojen teuraskuljetus & $\mathbf{2 8}$ & Sika ennen teurastusta & $\mathbf{4 2}$ \\
\hline Lihanauta ryhmäkarsinassa & $\mathbf{1 6}$ & Lihasiat ryhmäkarsinassa & $\mathbf{3 7}$ \\
\hline Munivat kanat & & Emakot porsitushäkissä & $\mathbf{2 1}$ \\
\hline Kanat ulkokanalassa & $\mathbf{8 2}$ & Emakot tiineytyshäkissä & $\mathbf{1 8}$ \\
\hline Kanat lattiakanalassa & $\mathbf{6 7}$ & Lampaat & \\
\hline Kanat virikehäkkikanalassa & $\mathbf{3 3}$ & Lampaat tilalla (pihatto, laidunnus) & $\mathbf{8 2}$ \\
\hline Broilerit & & Lampaiden teuraskuljetus & $\mathbf{5 0}$ \\
\hline Broilerit tilalla & $\mathbf{5 0}$ & Lampaiden teurastus & $\mathbf{3 8}$ \\
\hline Broilerit ennen teurastusta & $\mathbf{3 7}$ & Lypsylehmät & \\
\hline Broilerit hautomovaiheessa & $\mathbf{2 9}$ & Lypsylehmät pihatossa & $\mathbf{7 1}$ \\
\hline Broilerien teuraskuljetus & $\mathbf{1 9}$ & Lypsylehmät parsinavetassa & $\mathbf{2 4}$ \\
\hline
\end{tabular}

\section{Hyvinvointimerkin tärkeimmät toimenpiteet tuotantoeläinlajeittain}

Tärkeimmäksi sianlihantuotannon toimenpiteeksi nähtiin hyvä kohtelu ja käsittelykoulutus sekä ennaltaehkäisevä terveydenhuolto (Kuva 2). Hieman yllättäen vapaata porsimista ja tiineytystä ilman häkissä pitoa pidettiin vähemmän tärkeinä, vaikka hyvinvointia ei nähty kyseisissä tuotantomuodoissa kovin hyvällä tasolla (Taulukko 2). Myös olosuhteisiin ja käyttäytymiseen liittyviä tekijöitä kuten lisäelintilaa ja ulkoilumahdollisuutta sekä tonkimismateriaalin saatavuutta pidettiin vähintään tärkeinä, kuten myös montaa tekijää mittaavaa hyvinvointi-indeksiä.

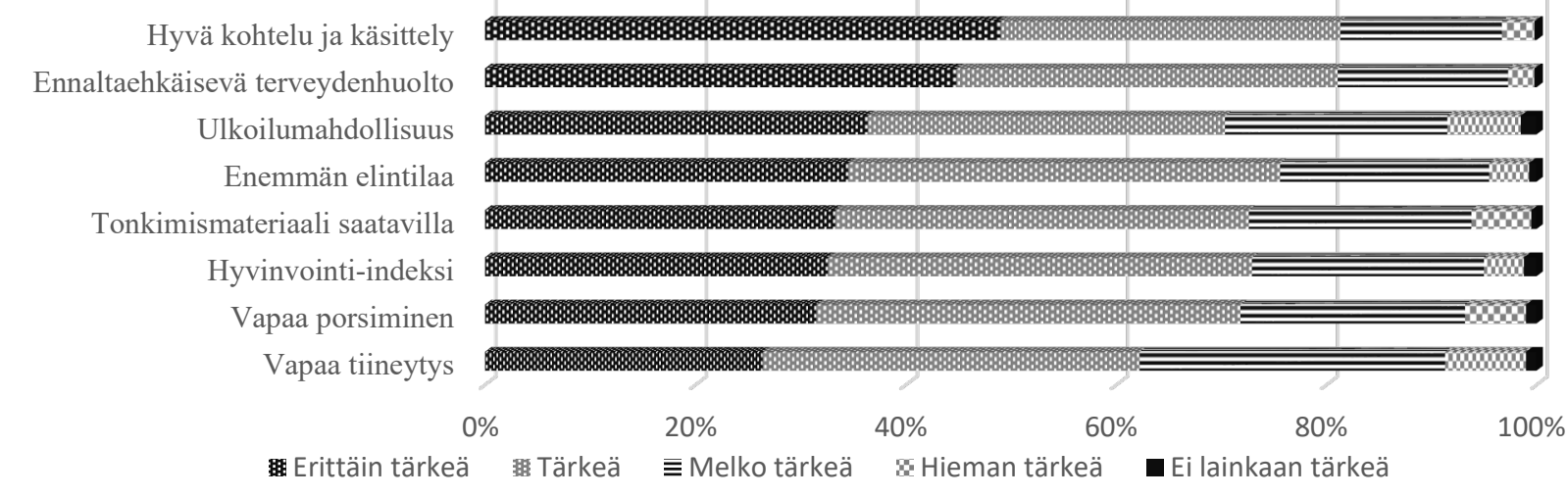

Kuva 2. Hyvinvointikriteerien tärkeys sianlihantuotannossa $(n=400)$

Lampailla tärkeimpinä kriteereinä pidettiin jatkuvaa vedensaantia ja laidunnusmahdollisuutta (noin 90 \% vastaajista piti tärkeänä tai erittäin tärkeänä, Kuva 3). Myös ulkoilu- ja jaloittelumahdollisuutta laidunkauden ulkopuolella sekä keritsemistä kahdesti vuodessa piti vähintään tärkeinä noin $80 \%$ vastaajista. Hyvän kohtelun ja käsittelyn koulutusta piti vähintään tärkeänä $88 \%$ vastaajista ja karitsoinnin valvontaa ja ennaltaehkäisevää terveydenhuoltoa noin $85 \%$ vastaajista. 


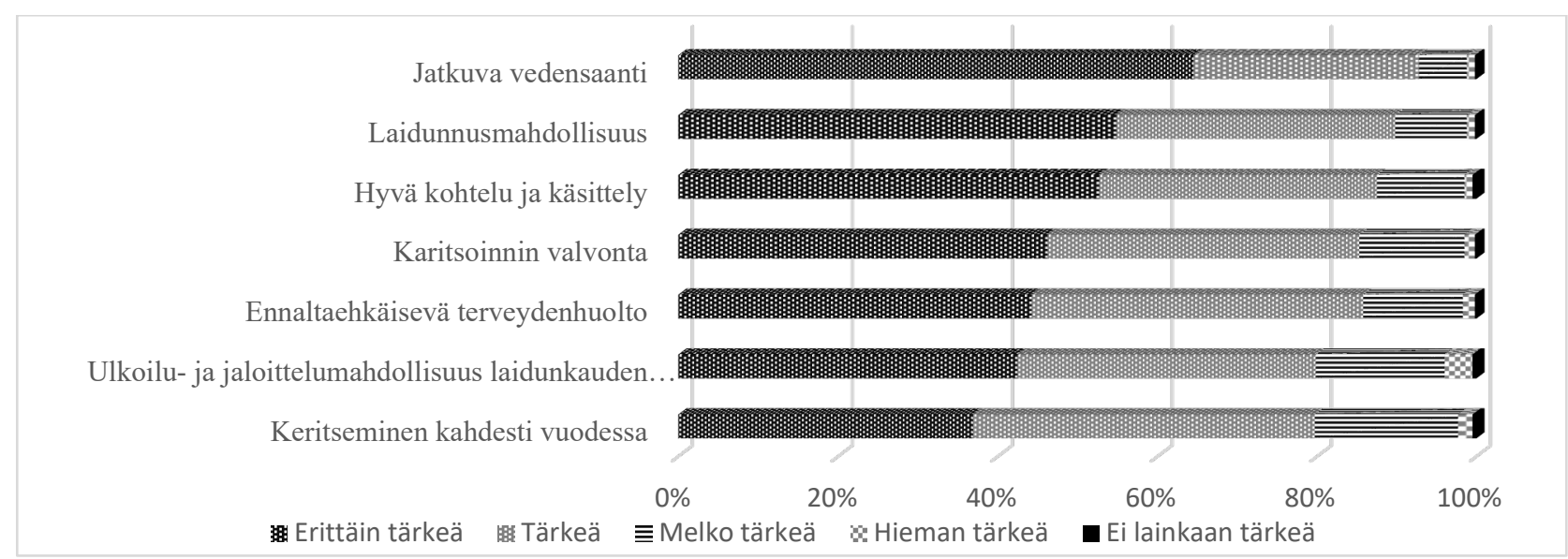

Kuva 3. Hyvinvointikriteerien tärkeys lampaanlihan tuotannossa $(n=400)$

Kanojen osalta tärkeimpinä kriteereinä pidettiin vapaata liikkumista ja lisäelintilaa (Kuva 4). Myös lajinomaista ruokintaa (esim. kokonaiset hyvät), ulkoilumahdollisuutta, kuopsutus- ja kylpemismahdollisuutta, hyvä kohtelu ja käsittely -koulutusta ja ennaltaehkäisevää terveydenhuoltoa piti vähintään tärkeänä noin $80 \%$ vastaajista. Ilmanlaadun seuranta nähtiin kriteereistä vähemmän tärkeänä kuin muut kriteerit.

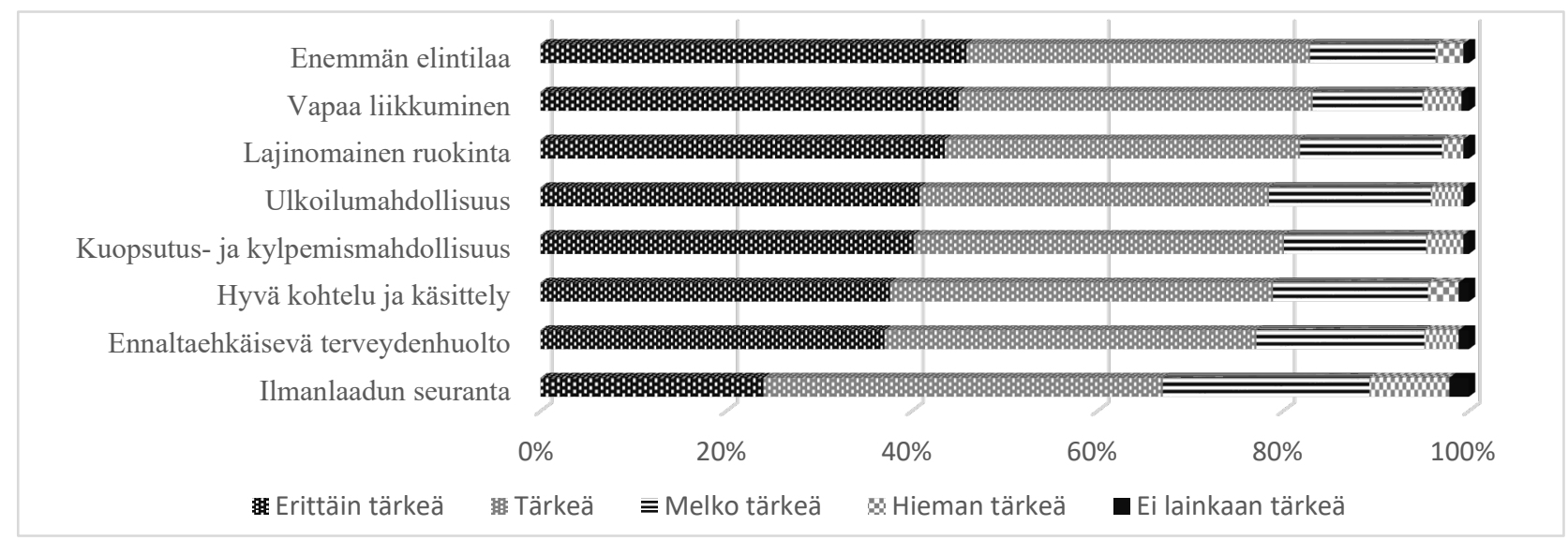

Kuva 4. Hyvinvointikriteerien tärkeys kananmunan tuotannossa $(n=400)$

Broilerintuotannon osalta tärkeimpinä pidettiin lisätilaa, virikkeiden käyttöä (esim. kylpylaatikot), hyvä käsittely ja kohtelu -koulutusta sekä mukavaa alustaa eli pehkun laatua (Kuva 5). Jalkaterveyden säännöllistä seurantaa tilalla sekä ritilätasojen käyttöä piti vähintään tärkeänä $71 \%$ vastaajista ja ennaltaehkäisevää terveydenhuoltoa $75 \%$ vastaajista. Hitaammin kasvava rotu oli tärkeä vain 53 prosentin mielestä vastaajista.

Naudoilla hyvinvointikriteereiksi esitettiin tuotantomuodon ja -vaiheen osalta yksilöidymmin lehmille laidunnusta sekä pihattonavettaa, vasikoille runsaampaa juottoa ja imemistarpeen tyydyttämistä ja lihanaudoille lisäelintilaa. Kaikille naudoille yhteisiä hyvinvointitoimenpiteitä olivat jatkuva vedensaanti, ennaltaehkäisevä terveydenhuolto, hyvä kohtelu ja käsittely -koulutus, jalkaterveyden seuranta, karkearehun jatkuva saanti, pehmeä makuualusta ja ulkoilumahdollisuus laidunkauden ulkopuolella. 


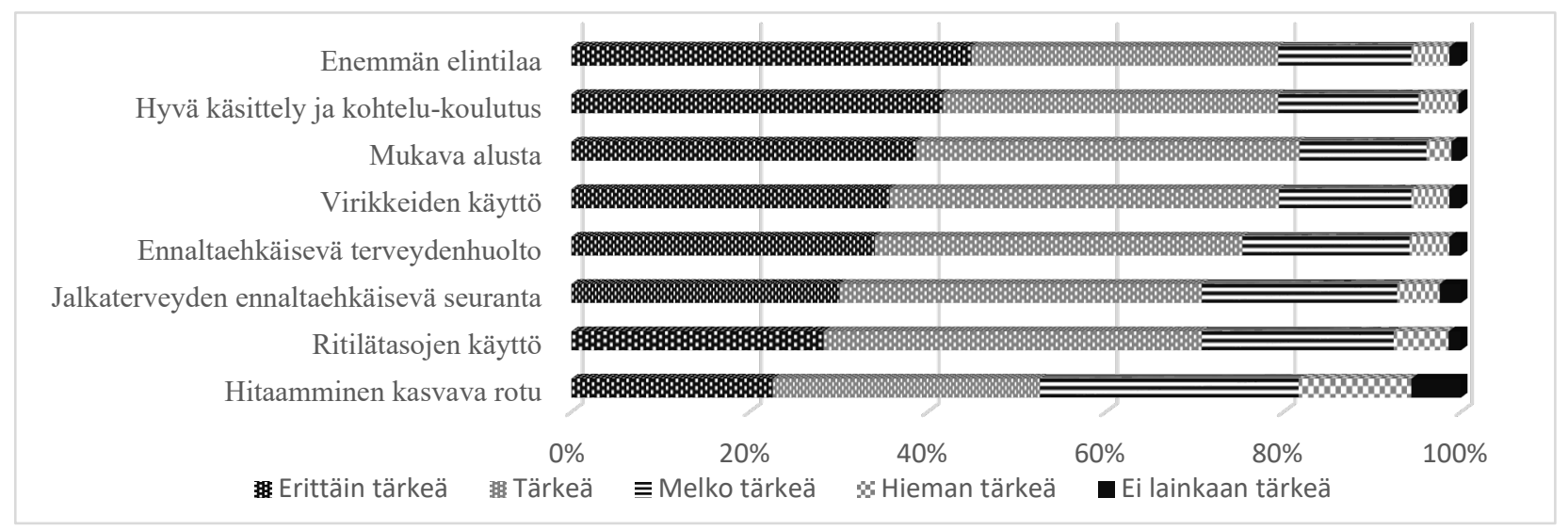

Kuva 5. Hyvinvointikriteerien tärkeys broilerintuotannossa $(\mathrm{n}=400)$

Tärkeimpänä nähtiin jatkuva vedensaanti (Kuva 6). Erittäin tärkeänä pidettiin jälleen hyvä kohtelu ja käsittely -koulutusta. Yli $80 \%$ piti vähintään tärkeänä myös ennaltaehkäisevää terveydenhuoltoa, jalkaterveyden seurantaa, lisätilaa lihanaudoille, lehmien vapaata liikkumista pihatossa ja lehmien laidunnusta.

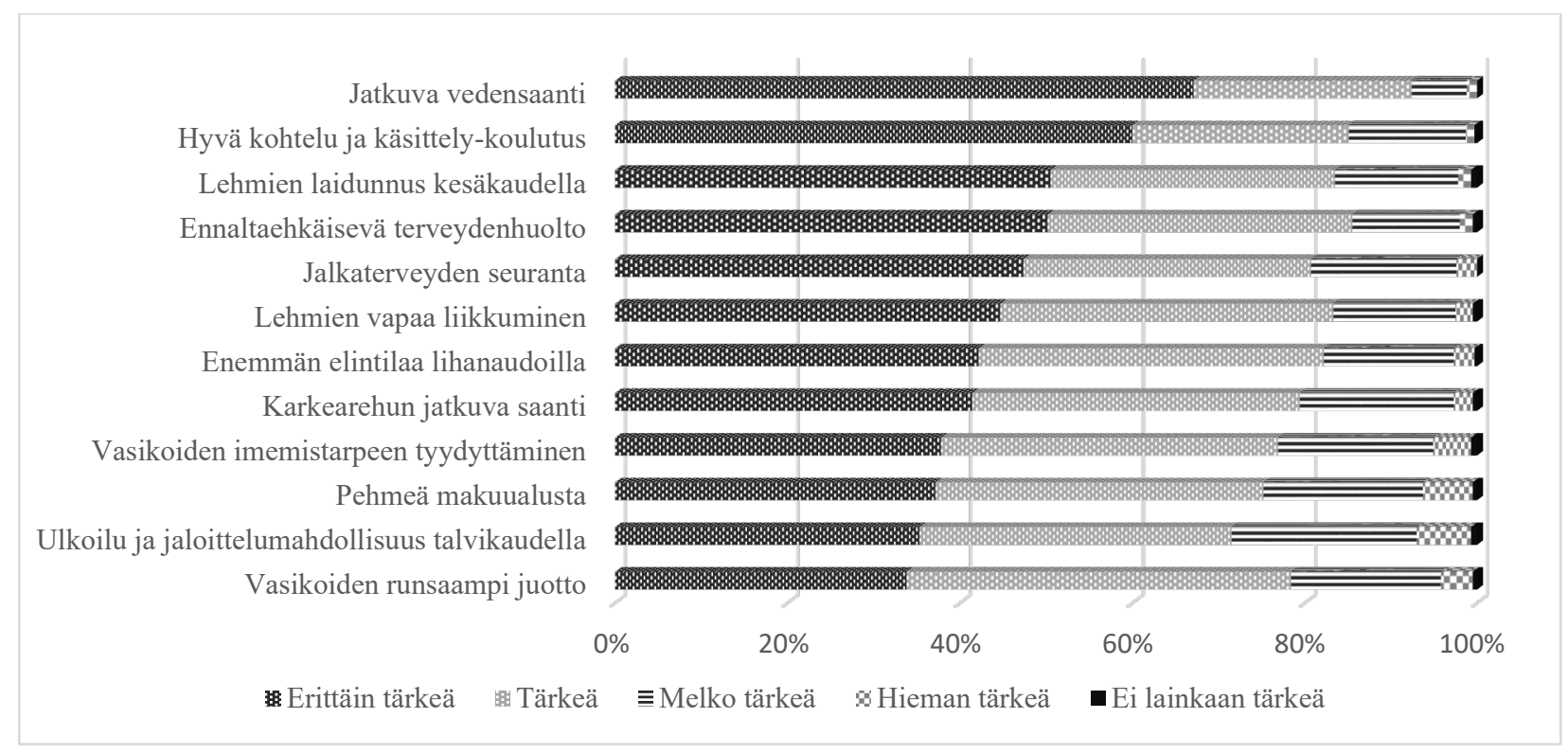

Kuva 6. Hyvinvointikriteerien tärkeys maidon- ja naudanlihantuotannossa ( $\mathrm{n}=400)$

\section{Hyvinvointituotteiden ostaminen}

Vastaajien $(\mathrm{n}=400)$ näkemystä hyvinvointituotteen ostamisesta tarkasteltiin viisiportaisella Likertasteikoilla. Vastaajista $76 \%$ koki hyvinvointimerkin tuotteen ostamisen positiiviseksi (valitsi 4 tai 5, viiden kuvatessa erittäin positiivista ja erittäin yhden negatiivista). Vastaajista $61 \%$ ostaisi hyvinvointimerkittyjä tuotteita, jos kotieläintuotannossa keskityttäisiin enemmän eläinten hyvinvointiin ja eri mieltä $9 \%$. Huolestuneita tuotantoeläinten hyvinvoinnista sen vaikuttaessa ostopäätökseen vastasi olevansa $52 \%$ ja eri mieltä asiasta $11 \%$. Hyvinvointimerkittyjen tuotteiden uskottiin olevan liian kalliita ostaa $29 \%$ mielestä vastaajista, kun taas eri mieltä vastaajista oli $32 \%$. Merkittävää on, että $68 \%$ vastaajista uskoo, että hyvinvointimerkityn tuotteen ostamisen parantaisi tuotantoeläinten hyvinvointia. Vastaajista lähes neljännes (24\%) epäili, että ei huomaisi hyvinvointimerkittyä tuotetta kaupan hyllystä, $43 \%$ huomatessa ja $55 \%$ vastaajista ei lähtisi hakemaan hyvinvointimerkittyjä tuotteita oma nykyisin käyttämäänsä ruokakauppaa kauempaa. Vain $15 \%$ olisi valmis lähtemään kauemmaksi. Markkinoilla olevia luomutuotteita oli ostanut tuotetyypistä riippuen (luomumaito, luomumunat ja luomuliha) 12-16 \% vastaajista vähintään viikoittain. Vähintään kuukausittain luomumaitoa oli ostanut 39\% vastaajista, luomumunia $46 \%$ vastaajista ja luomulihaa $40 \%$ vastaajista. Toisaalta $39 \%$ vastaajista ei ollut ikinä 
ostanut luomumaitoa, 28 \% luomumunia ja kolmannes luomulihaa. Kysyttäessä Hyvää Suomestatuotteista, $17 \%$ vastasi, ettei ollut koskaan ostanut niitä, kun taas $70 \%$ oli ostanut niitä vähintään kuukausittain.

\section{Tulosten tarkastelu}

Tarkastellessa kuluttajien näkemystä hyvinvoinnista eri tuotantomuodoissa, mielipide sikojen ja siipikarjan hyvinvoinnin matalammasta tasosta on tullut esiin jo aiemmissa kyselyissä (EHK 2013b). Myös kansainvälisesti tarkastellen kuluttajat pitävät broilereiden hyvinvoinnin matalatasoisena (Martelli 2010). Myös teurastamista edeltävästä hyvinvoinnista on saatu kuluttajien näkemyksiä aiemmissa tutkimuksissa (Clark ym. 2016), joissa kuluttajat näkivät hyvinvointia heikentävän pitkät teurastusmatkat ja etenkin ravinnon tai -vedenpuute teurasmatkan aikana sekä eläimen tainnutuksen epäonnistuminen.

Kuluttajien vähäinen tietoisuus eläintuotannosta sekä heikot yhteydet nousivat esille tämän tutkimuksen tuloksissa. Vähäinen tieto eläintuotannon käytännöistä ja yleensä vieraantuminen eläintuotannosta ovat nousseet esille aiemmissakin tutkimuksissa. Clark ym. (2016) totesivat meta-analyysissaan, että omaa subjektiivista tietoa lisäksi usein yliarvioidaan ja yhteydet tai kokemukset eläintuotannosta kertovat enemmän todellisesta tietotasosta kuin oma arvioitu tietämys. Tosin tässä tutkimuksessa vain $19 \%$ koki tietävänsä melko paljon tai paljon ja $45 \%$ vastaajista ei ollut yhteyksiä eläintuotantoon. Tämä voi selittää esimerkiksi sitä, miksi nautojen hyvinvoinnin nähtiin olevan korkeammalla tasolla. Laiduntavia lehmiä käytetään usein esimerkiksi mainostarkoituksessa ja ne luovat mielikuvaa mukavasta ympäristöstä ja elinmukavuudesta. Esimerkiksi sikojen osalta julkisuudessa on ollut negatiivista keskustelua häkkien käytön osalta, mikä myös heikentävät kuluttajien mielikuvaa eläinten hyvinvoinnista.

Vastaajille tärkeimmät hyvinvointikriteerit kuvaavat eläinten perustarpeita, kuten asianmukaista ravinnon ja veden saantia sekä hyvää terveydentilaa. Ennaltaehkäisevä terveydenhuolto sekä hyvän käsittelyn ja kohtelun koulutus ovat tärkeimpien kriteerien joukossa kaikilla lajeilla. Inhimillinen kohtelu sekä luonnollisuus (käyttäytymisen ja olosuhteiden näkökulmasta) on havaittu kuluttajille keskeisiksi myös aiemmissa tutkimuksissa (Blokhuis ym. 2003, Clark ym. 2016). Luonnollisuus liitetään usein myös riittävän tilaan ja ulospääsyyn. Lisäelintilan sekä ulospääsyn mahdollisuus näkyivät myös positiivisina/kannatettavina kriteereinä tässä tutkimuksessa. Ylipäätään liikkumisen vapaus etenkin naudoilla ja kanoilla nähtiin hyvin tärkeinä. Eläinten hyvinvointi oli valtaosan mielestä parantunut viime vuosina. Tämä on mielenkiintoinen tulos, sillä viimeaikaisissa tutkimuksissa nykyinen moderni tuotanto on herättänyt huolta eläinten hyvinvoinnin näkökulmasta, toisaalta sen hyviä puolia on ajateltu olevan parantunut hygieniataso ja myös tehokkuus omalta osaltaan (Clark ym. 2016). Paranemisen syyksi esitettiin muun muassa viranomaisten valvonnan tehostumista ja uusia tuotantoteknologioita.

\section{Johtopäätökset}

Kuluttajille tärkeimpiä hyvinvointikriteerejä olivat eläinten perustarpeisiin liittyvät tekijät, kuten ennaltaehkäisevä terveydenhuolto ja ravinnonsaanti. Näiden lisäksi myös monien muiden, kuten eläinten hyvän käsittelyn ja kohtelun koulutuksen sekä muiden lajinmukaista käyttäytymistä edistävien tekijöiden, nähtiin olevan tarpeellisia hyvinvointimerkinnässä. Myös ostohalukkuutta esiintyi tuloksissa, vaikka osa vastaajista epäili, sopiiko hyvinvointimerkittyjen tuotteiden hintataso heidän budjetilleen. Hyvinvointimerkityn tuotteen huomaamista hyllystä ja yleensä pakkausmerkintöjen huomioimista ei voi pitää itsestäänselvyytenä, mikä tuo haasteita hyvinvointimerkintäjärjestelmän markkinointiin. Kaiken kaikkiaan markkinoinnin osalta haastavaa on kuluttajien vähäinen tieto eläintuotannosta. 
Eläinperäiset mittarit mittaavat usein luotettavimmin eläinten hyvinvointia, mutta niiden käyttö voi olla resurssiperäisiä mittareita kalliimpaa. Etenkin niiden markkinointi kuluttajalle voi olla haaste. On helpompi myydä kuluttajalle tuotetta, jossa eläin on saanut olla pehmeällä makuualustalla ja nauttia laidunnuksesta kuin markkinoida pienempää porsaskuolleisuutta ja vähäisempiä ihovaurioita. Tulokset luovat kuitenkin mahdollisuuksia hyvinvointimerkinnän kehittämiseksi Suomen markkinoille, sillä eläinten hyvinvointi kiinnostaa suomalaisia ja useiden hyvinvointitekijöiden liittäminen eläintuotantoon ja hyvinvointijärjestelmään nähtiin tärkeiksi.

\section{Kiitokset}

Tämä tutkimus on osa Eläinten hyvinvointimerkintä suomalaisen eläintuotannon kilpailukyvyn ja laadun edistäjänä-hanketta. Hankkeen toteuttavat Luonnonvarakeskus ja Pellervon taloustutkimus ja sitä ovat rahoittaneet maatilatalouden kehittämisrahasto (MAKERA) sekä A-tuottajat, HKScan, Valio, Arla, Juustoportti food, Lidl, Maa- ja metsätaloustuottajain keskusliitto ja SEY Suomen eläinsuojelu.

\section{Kirjallisuus}

Barnett, J., Hemsworth, P., Cronin, G. \& Jongman, E. 2000. A review of the welfare issues for sows and piglets in relation to housing. Crop and Pasture Science 52:1-28. https://doi.org/10.1071/AR00057

Bessey, W. 2006. Welfare of Broilers: A review. World's Poultry Science Journal 62: 455-466. https://doi.org/10.1079/WPS2005108

Blokhuis, H. J., Jones, R. B., Geers, R., Miele, M., \& Veissier, I. 2003. Measuring and monitoring animal welfare: Transparency in the food product quality chain. Animal Welfare 12: 445-455.

Boissy, A., Jensen, M., Manteuffel, G. \& Moe, R. 2007. Assessment of Positive Emotions in Animals to Improve Their Welfare. Physiology \& Behavior 92: 375-97. https://doi.org/10.1016/j.physbeh.2007.02.003

Botreau, R., Bracke, M.B.M., Perny, P., Butterworth, A., Capdeville, J., Rennen, C.G. van \& Veissier, I. 2007. Aggregation of measures to produce an overall assessment of animal welfare. Part 2: analysis of constraints, Animal 1: 1188-1197. https://doi.org/10.1017/S1751731107000547

Botreau, R., Veissier, I. \& Perny, P. 2009. Overall assessment of cow welfare: strategy adopted in Welfare Quality®. Animal Welfare 18: 363-370.

Canali, E \& Keeling, L. 2016. Welfare Quality ${ }^{\circledR}$ project: from scientific research to on farm assessment of animal welfare. Italian Journal of Animal Science 8, 2009: Proceedings of the 18th ASPA Congress, Palermo, June 9-12, 2009. https://doi.org/10.4081/ijas.2009.s2.900

Clark, B., Stewart, G., Panzone, L., Kyriazakis, I. \& Frewer, L. 2016. A Systematic Review of Public Attitudes, Perceptions and Behaviours Towards Production Diseases Associated with Farm Animal Welfare. Journal of Agricultural and Environmental Ethics 29: 455-478. https://doi.org/10.1007/s10806-016-9615-x

Dawkins M., Donnelly, C. \& Jones, T. 2004 Chicken welfare is influenced more by housing conditions than by stocking density. Nature 427: 342-344. https://doi.org/10.1038/nature02226

Dwyer, C.M., 2008. Genetic and physiological determinants of maternal behavior and lamb survival: implications for low-input sheep management. Journal of Animal Science 86:246-258. https://doi.org/10.2527/jas.2007-0404

EHK 2013a. Häkkiporsituksesta luopumisen tuotannolliset ja taloudelliset vaikutukset. Eläinten hyvinvointikeskus 2013. https://mmm.fi/documents/1410837/1858027/Porsitusselvitys/c6f9206b-0e44-4031affb-a5390ea4b9d6/Porsitusselvitys.pdf

EHK 2013b. Animal welfare in Finland. A national report on animal welfare. Helsinki 2013. https://www.elaintieto.fi/wp-content/uploads/2015/12/Animal-Welfare-Report.pdf

EHK 2016. Eläinten hyvinvointi Suomessa. Kansallinen eläinten hyvinvointiraportti II. Helsinki 2016. https://www.elaintieto.fi/wp-content/uploads/2016/06/El\%C3\%A4inten_hyvinvointi_Suomessa.pdf

Eläinsuojelulaki 247/1996. https://www.finlex.fi/fi/laki/ajantasa/1996/19960247 
Eläinsuojeluasetus 396/1996. https://www.finlex.fi/fi/laki/ajantasa/1996/19960396

Hernandez-Mendo, O., von Keyserlingk, M.A.G., Veira, D.M. \& Weary, D.M. 2007. Effects of pasture on lameness of dairy cows. Journal of Dairy Science 2: 1209-1214. https://doi.org/10.3168/jds.S00220302(07)71608-9

Juustoportti 2020. Mitä vapaan lehmän maito on. https://www.juustoportti.fi/vapaalehma

Laki eräistä ohjelmaperusteisista viljelijäasetuksista 1360/2014. https://www.finlex.fi/fi/laki/ajantasa $/ 2014 / 20141360$

Lawrence, A., Vigors, B.\& Sandoe, P. 2019. What Is so Positive about Positive Animal Welfare? -A Critical Review of the Literature. Animals 9: 783. https://doi.org/10.3390/ani9100783

Lidl 2020. Ilona - hyvinvoivien lehmien maitoa. https://corporate.lidl.fi/vastuullisuus/tuotteet/ilona-maito https://www.juustoportti.fi/vapaanlehmantuotteet

MMM. 2018. Eläinsuojelulaista tulee eläinten hyvinvointilaki. Luettu 29.1.2020. https://mmm.fi/elainsuojelulaki

MMM 2020. Eläinten hyvinvointi. https://mmm.fi/elainten-hyvinvointi

Martelli, G. 2010. Consumers' perception of farm animal welfare: an Italian and European perspective. Italian Journal of Animal Science 8: 31-41. https://doi.org/10.4081/ijas.2009.s1.31

Roca-Fernandez, A.I., Ferris, C.P. \& Gonzalez-Rodriguez, A. 2013 Short communication. Behavioural activities of two dairy cow genotypes (HolsteinFriesian vs. Jersey x Holstein-Friesian) in two milk production systems (grazing vs. confinement). Spanish Journal of Agricultural Research 11: 120-126. https://doi.org/10.5424/sjar/2013111-2682

Ruokavirasto 2019. Eläintaudit Suomessa 2018. Ruokaviraston julkaisuja 4/2019.

https://www.ruokavirasto.fi/globalassets/tietoameista/julkaisut/julkaisusarjat/julkaisuja/elaimet/ruokaviraston_jul kaisuja_4_2019_elaintaudit_suomessa_2018.pdf

Ruokavirasto 2020. Laatuvastuu. https://www.ruokavirasto.fi/yritykset/elintarvikeala/elintarvikealan-yhteisetvaatimukset/kansalliset-laatujarjestelmat/laatuvastuu/

Scollo, A, Contiero, B, Gottardo, F. 2016. Frequency of tail lesions and risk factors for tail biting in heavy pig production from weaning to $170 \mathrm{~kg}$ live weight. The Veterinary Journal 207: 92-98.

https://doi.org/10.1016/j.tvj1.2015.10.056

SVT 2020a Suomen virallinen tilasto (SVT): Väestön koulutusrakenne [verkkojulkaisu].

ISSN=1799-4586. Helsinki: Tilastokeskus. Viitattu: 31.1.2020. http://www.stat.fi/til/vkour/yht.html

SVT 2020b. Suomen virallinen tilasto (SVT): Tulonjakotilasto [verkkojulkaisu].

ISSN=1795-8121. Helsinki: Tilastokeskus. Viitattu: 31.1.2020. http://www.stat.fi/til/tjt/index.html

SVT 2020c. Suomen virallinen tilasto (SVT): Väestön koulutusrakenne [verkkojulkaisu].

ISSN=1799-4586. Helsinki: Tilastokeskus. Viitattu: 31.1.2020. http:/www.stat.fi/til/vkour/index.html

SVT 2020d. Työssäkäynti [verkkojulkaisu].

ISSN=1798-5528. Helsinki: Tilastokeskus. Viitattu: 31.1.2020. http://www.stat.fi/til/tyokay/tau.html

Turner, S.P., Ewen, M., Rooke, J. \& Edwards, E. 2000. The effect of space allowance on performance, aggression and immune competence of growing pigs housed on straw deep litter at different group sizes. Livestock Production Science 66: 47-55. https://doi.org/10.1016/S0301-6226(00)00159-7

Vermeer, H.M., Dirx-Kuijken, N. \& Bracke, M. 2017 Exploration Feeding and Higher Space Allocation Improve Welfare of Growing-Finishing Pigs. Animals (Basel) 7: 36. https://doi.org/10.3390/ani7050036

Von Keyserlingk, M., Rushen, J., de Passillé, A. \& Weary, D. 2009. Invited review: The welfare of dairy cattleKey concepts and the role of science. Journal of Dairy Science 92: 4101-4111. https://doi.org/10.3168/jds.20092326 
Wallenius, E. 2020. Factors affecting Animal Welfare with emphasis on the Finnish livestock production. Literature review. Julkaisematon käsikirjoitus.

Washburn, S.P. White, S.L. Green, J.T., Jr. \& Benson G.A. 2002 Reproduction, mastitis, and body condition of seasonally calved Holstein and Jersey cows in confinement or pasture systems. Journal of Dairy Science 85: 105111 Welfare Quality 2018. Welfare Quality Network. https://doi.org/10.3168/jds.S0022-0302(02)74058-7

Welfare Quality 2018. Welfare Quality network. http://www.welfarequality.net/en-us/home/

Wischner, D., Kemper, N. \& Krieter, J. 2009. Nest-building behaviour in sows and consequences for pig husbandry. Livestock Science 124: 1-8. https://doi.org/10.1016/j.livsci.2009.01.015 